\title{
PENINGKATAN SUHU BAYI PREMATUR MELALUI TERAPI SENTUHAN
}

\author{
Ema Hikmah $^{1,2^{*}}$, Yeni Rustina ${ }^{3}$, Hening Pujasari ${ }^{3}$ \\ 1. Poltekkes Kemenkes Bandung, Jawa Barat 40161, Indonesia \\ 2. Program Studi Magister Fakultas Ilmu Keperawatan Universitas Indonesia, Depok 16424, Indonesia \\ 3. Fakultas Ilmu Keperawatan Universitas Indonesia, Depok 16424, Indonesia \\ *Email: mamah_beera@ymail.com
}

\begin{abstract}
Abstrak
Terapi sentuhan merupakan salah satu terapi nonfarmakologis yang dapat diberikan pada bayi prematur. Tujuan penelitian mengidentifikasi pengaruh terapi sentuhan terhadap suhu dan nadi bayi prematur di ruang perinatologi RS X Tangerang. Desain penelitian menggunakan kuasi eksperimen dengan pre dan post test. Teknik pengambilan sampel dengan cara consecutive sampling. Responden berjumlah 30 bayi prematur, dengan 15 bayi pada kelompok intervensi dan 15 bayi pada kelompok kontrol. Pengujian rata-rata suhu dan nadi pada kelompok kontrol dan kelompok intervensi menggunakan uji $t$-test. Hasil penelitian menunjukkan peningkatan rata-rata suhu bayi prematur secara signifikan pada kelompok intervensi $(\mathrm{p}=0,000, \alpha=$ $0,05)$. Kesimpulannya, terapi sentuhan dapat meningkatkan suhu bayi prematur. Disarankan agar terapi sentuhan dapat diterapkan dalam asuhan keperawatan pada bayi prematur.
\end{abstract}

Kata kunci: bayi prematur, nadi, suhu, terapi sentuhan

\begin{abstract}
Therapeutic touch is one of non pharmacologic therapy that can be given to premature babies. The purpose of study was to identify the effects of therapeutic touch on the temperature and pulse of premature babies at Perinatal Unit, X Hospital in Tangerang. Quasi-experimental research design was used with pre and post test. Sampling technique was by consecutive sampling. Respondents were 30 premature infants, with 15 infants in the intervention group and 15 infants in the control group. The average temperature and pulse in the control group and intervention group was measured by t-test. The results showed an increase in the average temperature of premature infants in the intervention group were significant $(p=0,000, \alpha=$ $0,05)$. In conclusion, therapeutic touch can increase the temperature of premature infants. It is recommended that therapeutic touch can be applied in nursing care in preterm infants.
\end{abstract}

Keywords: premature infants, pulse, temperature, touch therapy

\section{Pendahuluan}

Angka kematian dan kesakitan bayi dipengaruhi berbagai faktor, salah satunya adalah keadaan pada waktu bayi dilahirkan. Berdasar data di Indonesia menggambarkan bahwa setiap tahun diperkirakan sekitar 350.000 bayi lahir dengan prematur atau berat badan lahir rendah. Pola penyakit penyebab kematian menunjukkan bahwa proporsi penyebab kematian neonatal pada kelompok umur 0-7 hari tertinggi prematur dan berat badan lahir rendah (35\%), kemudian asfiksia (33,6\%) (Depkes, 2008).

Jumlah bayi prematur saat ini semakin meningkat. Data yang diungkapkan oleh World Health Organization (WHO) menyebutkan bahwa satu dari sepuluh kelahiran adalah bayi prematur.
Prematuritas ini menyebabkan angka kematian perinatal cukup tinggi. Berdasarkan studi yang dilakukan antara pertengahan tahun 1990 hingga 2007, ditemukan sekitar $85 \%$ bayi di Asia lahir sebelum waktunya yakni 37 minggu. Jumlah tersebut sekitar 77 juta bayi sedangkan di Afrika terdapat lebih dari 47 juta bayi prematur dilahirkan setiap tahunnya. Sementara di Eropa, kelahiran bayi prematur mencapai sekitar $6,2 \%$ setiap tahun pada tahun 2006, sedangkan di Amerika Latin dan Karibia 9,1\%.

Bayi prematur adalah bayi yang dilahirkan dengan usia gestasi atau kehamilan kurang dari 37 minggu dan berat badan rendah (Wong \& Hockenberry, 2004). Pada bayi prematur, kematangan semua organ tubuh bayi belum tercapai dengan baik. 
Keadaan ini menyebabkan perawatan bayi prematur harus dilakukan dengan baik terutama menjaga kestabilan suhu dan frekuensi denyut jantung. Apabila semua sistem diperhatikan dengan baik maka bayi dapat bertahan dan tumbuh kembang dengan baik.

Menurut Wong dan Hockenberry (2004), bayi yang dilahirkan dengan berat badan kurang dari 2500 gram, duapuluh kali lebih besar akan mengalami kematian di bulan pertama kehidupannya dibanding dengan bayi yang lahir dengan berat badan yang normal. Risiko akan meningkat lebih tinggi pada bayi yang di lahirkan dengan berat badan kurang dari 1500 gram.

Gangguan yang terjadi pada bayi prematur disebabkan belum matangnya semua organ bayi, diantaranya yaitu gangguan susunan saraf pusat. Gangguan ini sering mengakibatkan perdarahan otak, leukomalasia (pengapuran) otak dan henti nafas. Henti nafas adalah bayi secara mendadak berhenti nafasnya karena pengaturan nafas di otak dan otot bantu nafas pada bayi prematur belum sempurna.

Bayi yang lahir prematur juga mempunyai paruparu yang belum berfungsi dengan baik, salah satunya karena produksi surfaktan yang masih sedikit, sehingga pengembangan paru pada bayi prematur belum berkembang dengan baik dan biasanya bayi mengalami sesak nafas. Jantung pada bayi prematur sering mengalami ketidaksempurnaan penutupan pembuluh darahnya atau yang sering disebut Patent Ductus Arteriosus (PDA) yang dapat menyebabkan denyut jantung semakin cepat, sindroma gawat nafas dan gagal jantung (Wong \& Hockenberry, 2004).

Kualitas hidup bayi prematur harus ditingkatkan. Perawat di ruang perinatologi sebaiknya dapat melakukan perawatan dengan memperhatikan konservasi energi bagi bayi dan mencari metode perawatan terhadap bayi prematur sesuai dengan perkembangan yang ada saat ini, salah satunya adalah memberikan terapi sentuhan pada bayi prematur.
Terapi sentuhan di Indonesia sudah diketahui secara turun-temurun. Terapi sentuhan pada bayi merupakan gerakan sentuhan lambat dan lembut. Banyak penelitian tentang terapi sentuhan pada bayi ini, diantaranya adalah membuktikan bahwa terapi sentuhan pada bayi dapat meningkatkan pertumbuhan berat badan, meningkatkan suhu dan membuat bayi lebih nyaman dan lebih tenang pada saat tidur (Dieter, et al., 2003).

Hasil penelitian Diego, Field, dan Reif (2008), mengungkapkan penelitian mengenai terapi sentuhan yang dilakukan pada bayi prematur dapat meningkatkan suhu tubuh dibandingkan dengan bayi prematur yang tidak dilakukan terapi sentuhan. Penelitian yang lain tentang terapi sentuhan juga dilakukan oleh Dieter, et al. (2003). Hasil penelitian ini adalah pada kelompok bayi yang dilakukan terapi sentuhan mengalami kenaikan berat badan secara signifikan.

Kenaikan berat badan dengan terapi sentuhan juga memberikan hasil yang sama dengan penelitian yang dilakukan Lahat, et al. (2007). Penelitian yang ada mengenai terapi sentuhan belum ada yang mengaitkan dengan kestabilan suhu dan frekuensi nadi sehingga perlu dilakukan penelitian lebih lanjut mengenai pengaruh terapi sentuhan pada bayi prematur terhadap kestabilan suhu dan frekuensi nadi. Penelitian ini bertujuan untuk mengidentifikasi pengaruh terapi sentuhan pada bayi prematur terhadap suhu dan frekuensi nadi. Hasil penelitian ini diharapkan dapat memberikan masukan dan bahan pertimbangan bagi perawat untuk memberikan terapi sentuhan pada bayi prematur di ruang perinatologi.

\section{Metode}

Penelitian ini menggunakan desain penelitian kuasi-eksperimen, dengan tipe nonequivalent control group design pre dan post test. Intervensi yang diberikan adalah memberikan terapi sentuhan pada kelompok perlakuan. Sampel dalam penelitian ini berjumlah 15 bayi prematur untuk masingmasing kelompok sehingga total sampel adalah 30 orang. 
Teknik pengambilan sampel menggunakan cara consecutive sampling, yaitu dengan cara semua subyek yang datang dan memenuhi kriteria pemilihan dimasukkan dalam penelitian sampai jumlah subyek penelitian terpenuhi. Pengumpulan data dilakukan pada 14 Mei - 14 Juni 2010 di ruang perinatologi RS X Tangerang. Alat yang digunakan dalam penelitian berupa termometer digital untuk mengukur suhu dan pulse oxymetri untuk mengukur frekuensi nadi bayi prematur.

Kegiatan penelitian ini meliputi tindakan terapi sentuhan pada kelompok intervensi yang diberi sebanyak tiga kali dalam sehari. Tindakan ini dilakukan pada pagi hari setelah minum ASI/ PASI, pada siang hari setelah minum ASI/ PASI dan satu jam kemudian setelah terapi sentuhan yang kedua. Tindakan terapi sentuhan dilakukan selama 15 menit selama lima hari berturut-turut. Pengukuran suhu dan frekuensi nadi dilakukan dua kali yaitu; pengukuran pada pagi hari sebelum tindakan terapi sentuhan yang pertama dan pengukuran yang kedua sesaat setelah dilakukan terapi sentuhan yang ketiga. Pengukuran suhu dan frekuensi nadi pada kelompok kontrol dilakukan satu jam sebelum minum ASI/ PASI pada pagi hari dan pengukuran yang kedua satu jam setelah minum ASI/ PASI pada siang hari.

Analisis data penelitian ini diolah dengan program statistik. Analisis yang dilakukan secara univariat, bivariat, dan multivariat. Analisa univariat untuk menjelaskan variabel jenis kelamin, berat badan, usia gestasi, usia dan suhu lingkungan. Analisis bivariat untuk sampel berpasangan digunakan uji t-test dependen dan untuk data yang tidak berpasangan dilakukan uji t-test independen. Analisis multivariat menggunakan regresi linier untuk semua variabel dependen bersifat numerik.

\section{Hasil}

Hasil penelitian menunjukkan bahwa mayoritas jenis kelamin bayi prematur pada penelitian ini adalah perempuan sebanyak $66,7 \%$ (lihat tabel 1). Selain itu, hasil penelitian ini juga menggambarkan data yang bersifat numerik (lihat tabel 2). Setelah dianalisis didapatkan bahwa rerata usia gestasi bayi prematur adalah 31,70 minggu dengan standar deviasi 2,25. Bayi prematur mempunyai usia rerata 10,87 hari dengan standar deviasi 4,22. Berat badan bayi prematur menunjukkan rerata 1767,67 gram dengan standar deviasi 330,65. Suhu lingkungan yang diterima oleh bayi prematur adalah rerata $32,17^{\circ} \mathrm{C}$ dengan standar deviasi 1,62.

\section{Perbandingan Rerata Selisih Suhu dan Nadi Sebelum dan Setelah Terapi Sentuhan pada Kelompok Intervensi dan Kelompok Kontrol}

Rerata suhu pada bayi prematur sebelum dilakukan terapi sentuhan pada kelompok intervensi adalah 36,69, dengan standar deviasi 0,15 dan setelah diberikan terapi sentuhan didapatkan rerata suhu 36,87 dengan standar deviasi 0,19. Analisis lebih lanjut menunjukkan bahwa adanya perbedaan yang bermakna antara suhu pada bayi prematur sesudah pemberian terapi sentuhan terhadap kelompok intervensi, dengan peningkatan rerata suhu pada bayi prematur $0,18(\mathrm{p}=0,000, \alpha=0,05)$.

Rerata nadi pada bayi prematur sebelum dilakukan terapi sentuhan pada kelompok intervensi adalah 135,67, dengan standar deviasi 5,15, dan setelah diberikan terapi sentuhan didapatkan bahwa rerata nadi 134,27 dengan standar deviasi 5,93. Analisis lebih lanjut menunjukkan tidak adanya perbedaan yang bermakna antara nadi pada bayi prematur sebelum dan sesudah pemberian terapi sentuhan.

Tabel 1. Distribusi Responden Berdasarkan Jenis Kelamin

\begin{tabular}{lcccccc}
\hline \multicolumn{1}{c}{ Jenis Kelamin } & \multicolumn{2}{c}{ Intervensi } & Kontrol & \multicolumn{2}{c}{ Total } & \% \\
\hline Perempuan & 7 & $46,7 \%$ & 3 & 20 & 10 & $33,3 \%$ \\
Laki-laki & 8 & $53,3 \%$ & 12 & 80 & 20 & $66,7 \%$ \\
\hline
\end{tabular}


Dapat disimpulkan bahwa tidak adanya perbedaan yang bermakna antara bayi yang diberikan terapi sentuhan sebelum dan sesudah intervensi 1,40 $(\mathrm{p}=$ $0,30, \alpha=0,05$ ) (lihat tabel 3).

\section{Perbedaan Suhu dan Nadi Sesudah Intervensi antara Kelompok Intervensi dan Kontrol}

Perbedaaan suhu dan nadi diidentifikasi sebagai nilai perbedaan post test antara kedua kelompok. Hasil penelitian ini menunjukkan bahwa rerata peningkatan suhu bayi prematur yang dirawat di ruang perinatologi pada kelompok intervensi adalah 0,18 dengan standar deviasi 0,11, sedangkan pada pada kelompok kontrol adalah 0,003 dengan standar deviasi 0,29.

Analisis lanjut didapatkan bahwa tidak adanya perbedaan yang bermakna selisih rerata suhu antara kelompok intervensi dan kelompok kontrol $(\mathrm{p}=$ 0,057, $\alpha=0,05)$, juga tidak ada perbedaan yang signifikan selisih rerata penurunan nadi antara kelompok intervensi dengan kelompok kontrol $(\mathrm{p}=$ $0,70, \alpha=0,05)$.

\section{Pembahasan}

Pemberian terapi sentuhan pada bayi prematur dapat meningkatkan suhu bayi prematur. Penelitian ini sejalan dengan penelitian yang dilakukan oleh Diego, Field, dan Reif (2008) yang menjelaskan bahwa terapi sentuhan bermakna terhadap kenaikan suhu bayi prematur. Penelitian mengenai terapi sentuhan ini banyak dikaitkan dengan kenaikan berat badan bayi prematur dan hampir rata-rata berpengaruh signifikan terhadap kenaikan berat badan bayi prematur. Hal ini sesuai dengan penelitian yang dilakukan Glass, et al. (1975), tentang dampak suhu lingkungan terhadap berat badan bayi.

Hasil penelitian ini menunjukkan pada kelompok dengan suhu abdominal $36^{\circ} \mathrm{C}$ memperlihatkan peningkatan pertambahan berat dan panjang lebih baik dibandingkan dengan kelompok suhu abdominal yang lebih rendah. Keadaan tersebut dimungkinkan karena bayi yang dirawat pada lingkungan yang lebih hangat tidak memerlukan banyak kalori untuk mempertahankan suhu tubuh, sedangkan bayi di dalam lingkungan yang lebih dingin memerlukan lebih banyak kalori untuk mengatur suhu tubuhnya, sehingga kalori yang tersedia untuk pertumbuhan lebih sedikit.

Analisis lebih lanjut menunjukkan bahwa tidak ada perbedaan yang bermakna antara nadi pada bayi prematur sebelum dan sesudah pemberian terapi sentuhan. Kesimpulan yang dapat diambil adalah tidak ada perbedaan yang bermakna antara bayi yang diberi terapi sentuhan sebelum dan sesudah intervensi $1,40(p=0,30, \alpha=0,05)$.

Penelitian ini sejalan dengan penelitian Harrison, et al. (1996), yang mengidentifikasi pengaruh terapi sentuhan terhadap kadar kortisol serum, penggunaan oksigen dan fototerapi, lama hari rawat di rumah sakit, berat badan, dan denyut nadi pada bayi prematur. Hasil penelitian oleh Harrison, et al. (1996) mengungkapkan terapi sentuhan yang dilakukan pada bayi prematur hasilnya bermakna terhadap kadar kortisol serum, lama hari rawat, tetapi hasilnya tidak signifikan terhadap penggunaan oksigen dan frekuensi nadi prematur.

Tabel 2. Distribusi Responden Berdasarkan Usia Gestasi, Usia, Berat Badan, dan Suhu

\begin{tabular}{lcccc}
\hline \multicolumn{1}{c}{ Variabel } & Mean & SD & Min-Maks & 95\% CI \\
\hline Usia gestasi & 31,70 & 2,25 & $28-35$ & $30,86-32,54$ \\
Usia & 10,87 & 4,22 & $7-22$ & $9,29-12,44$ \\
Berat badan & 1767,67 & 330,65 & $980-2400$ & $1644,2-1891,13$ \\
Suhu lingkungan & 32,17 & 1,62 & $30-35$ & $31,56-32,77$ \\
\hline
\end{tabular}


Penelitian lain yang dilakukan oleh ModricinMcCarthy (1992) mengenai terapi sentuhan terhadap bayi prematur menunjukkan hasil yang bermakna terhadap kualitas tidur dan aktifitas motorik, tetapi hasilnya tidak bermakna terhadap nadi dan saturasi oksigen. Pada penelitian yang dilakukan oleh Harrison, et al. (2000), antara lain yaitu mencoba mengidentifikasi pengaruh terapi sentuhan terhadap kualitas tidur, orientasi stabilitas autonomy Brazelton Neonatal Behavioral Assesment Scale (BNBS), saturasi oksigen dan frekuensi denyut nadi. Penelitian yang dilakukan terhadap 12 bayi prematur masing-masing di kelompok kontrol dan intervensi menunjukkan bahwa ada perbedaan yang bermakna antara terapi sentuhan terhadap kualitas tidur dan skor BNBS dengan melihat kualitas tidur dan skor BNBS.

Untuk saturasi oksigen tidak ada perbedaan yang bermakna. Pada frekuensi nadi hasilnya menunjukkan bahwa adanya perbedaan, yaitu peningkatan sekitar 6 denyut/menit. Jika melihat pada hasil tersebut, pengaruh terapi sentuhan tidak berpengaruh terhadap denyut nadi. Hal ini kemungkinan terjadi karena ada berbagai macam faktor yang mempengaruhi denyut nadi pada bayi prematur. Berbagai tindakan yang dilakukan pada bayi di ruangan perinatologi berbeda-beda tergantung kebutuhan dari bayi tersebut. Semakin sering bayi mendapatkan suatu tindakan yang menyakitkan maka akan mempengaruhi denyut nadi, pada kelompok kontrol maupun kelompok intervensi.

Hasil penelitian ini menunjukkan bahwa adanya penurunan frekuensi nadi pada bayi prematur di kelompok intervensi, tetapi setelah dilakukan uji analisis ternyata perbedaan tersebut hasilnya tidak bermakna. Menurut hasil pengamatan dan observasi, hal ini disebabkan oleh selama proses penelitian hampir $80 \%$ bayi prematur yang dirawat di ruang perinatologi mendapatkan sebanyak dua kali penusukan selama periode terapi sentuhan yaitu pada pagi hari untuk pengambilan darah dan penggantian jarum infus yang bengkak. Peneliti berasumsi bahwa penusukan yang diterima oleh bayi prematur akan membuat rasa sakit yang akan meningkatkan frekuensi nadi, sehingga hasil penelitian tidak berpengaruh terhadap frekuensi nadi, pada kelompok kontrol maupun kelompok intervensi.

Tabel 3. Perbandingan Rata-rata Selisih Suhu dan Nadi

\begin{tabular}{|c|c|c|c|c|c|}
\hline Variabel & Kelompok & Mean & SD & df & $\mathbf{p}$ \\
\hline \multirow[t]{7}{*}{ Suhu } & Intervensi & & & \multirow{7}{*}{14} & \multirow{4}{*}{0,000} \\
\hline & Sebelum & 36,69 & 0,15 & & \\
\hline & Setelah & 36,87 & 0,19 & & \\
\hline & Perbedaan & 0,18 & 0,20 & & \\
\hline & Kontrol & 36.77 & 0.21 & & \multirow{3}{*}{0,53} \\
\hline & Sebelum & 36,80 & 0,20 & & \\
\hline & $\begin{array}{l}\text { Setelah } \\
\text { Perbedaan }\end{array}$ & 0,03 & 0,11 & & \\
\hline \multirow{7}{*}{ Nadi } & Intervensi & & & \multirow{7}{*}{14} & \multirow{4}{*}{0,30} \\
\hline & Sebelum & 135,67 & 5,15 & & \\
\hline & Setelah & 134,27 & 5,93 & & \\
\hline & Perbedaan & $-1,4$ & 5,04 & & \\
\hline & Kontrol & 142,13 & 5,29 & & \multirow{3}{*}{0,45} \\
\hline & Sebelum & 142,80 & 5,4 & & \\
\hline & Perbedaan & $-0,67$ & 0,33 & & \\
\hline
\end{tabular}




\section{Kesimpulan}

Hasil penelitian ini menyimpulkan bahwa terapi sentuhan efektif dalam meningkatkan suhu bayi prematur. Berdasarkan hasil penelitian tersebut, penelitian merekomendasikan untuk dilakukan penelitian tentang terapi sentuhan yang lain dengan populasi yang lebih besar. Direkomendasikan juga untuk penelitian lanjutan terapi sentuhan dengan berbagai masalah kesehatan yang ada pada bayi prematur (WK, NN, DW).

\section{Referensi}

Depkes, RI. (2008). Peta kesehatan Indonesia tahun 2007: Survei demografi dan kesehatan Indonesia (SDKI) 2007. Jakarta: Pusat Data dan Informasi Departemen Kesehatan RI.

Diego, M.A., Field, T.M., \& Reif, M.H. (2008). Temperature increase in preterm infant during massage therapy. Diperoleh dari http://www. ncbi.nlm.nih.gov/pmc/articles/PMC2262938/.

Dieter, J., Field, T.M., Reif, M.H., Emory, E.K., \& Redzepi, M. (2003). Stable preterm infant gain more weight and sleep less after five days of massage theraphy. Diperoleh dari http:// jpe-psy.oxfordjournals.org/cgi/content/abstract/ 28/6/403.
Glass, L., Lala, R.V., Jaiswal, V., \& Nigam, S.K. (1975). Effect of thermal environment and caloric intake on head growth of low birthweight infants during late neonatal period. Arch Dis Child, 50 (7), 571-573.

Harrison, L., Olivet, L., Cuningham, K, et al. (1996). Effect of gentle human touch on preterm infants: Pilot study result. Diperoleh dari https://www.cebp.nl/vault_public/filesystem/ $? \mathrm{ID}=1948$.

Harrison, L., et al. (2000). Effect of developmental, health status, and environmental available on preterm infants responses to a gentle of human touch intervention. Alabama: Johnson and Johnson Institute.

Lahat, S., et al. (2007). Energy expenditure in growing preterm infants receiving massage therapy. Diperoleh dari http://www.jacn.org/cgi/content/ abstract/26/4/356.

Modricin-McCarthy, M.A. (1992). The physiological and behavioral effects of a gentle human touch nursing intervention on preterm infants (Doctoral Dissertation, University of Tennesse, Knoxville). Dissertation Abstracts International, 54B (3), 1336.

Wong, D.L., \& Hockenberry, M.J. (2004). Wong's clinical manual of pediatric nursing (6th Ed.). St. Louis: Mosby Inc. 